\title{
Sea cliff at Glowe: stratigraphy and absolute age chronology of the Jasmund Pleistocene sedimentary record
}

\author{
Michael Kenzler and Heiko Hüneke
}

Institute of Geography and Geology, University of Greifswald, Friedrich-Ludwig-Jahn-Str. 17a, Greifswald, 17487, Germany

Correspondence: Michael Kenzler (kenzlerm@uni-greifswald.de)

Relevant dates: $\quad$ Published: 15 August 2019

How to cite: Kenzler, M. and Hüneke, H.: Sea cliff at Glowe: stratigraphy and absolute age chronology of the Jasmund Pleistocene sedimentary record, DEUQUA Spec. Pub., 2, 43-50, https://doi.org/10.5194/deuquasp-2-43-2019, 2019.

Abstract: $\quad$ Four remarkable Pleistocene cliff outcrops scattered across the peninsula of Jasmund exhibit the dynamics of the Scandinavian Ice Sheet during the Weichselian glaciation in this area. The investigated sites display up to $30 \mathrm{~m}$ thick sequences of glacial tills with intercalated (glaci)fluvial to (glaci)lacustrine sediments. Based on detailed lithofacies analyses and a physical age chronology, we trace the reconstruction of the depositional sequences and their corresponding stratigraphic position within the Weichselian record.

1 The Weichselian glaciation in the southwestern Baltic Sea area

This article gives an overview of the current state of research on the peninsula of Jasmund, with special consideration given to the stratigraphy of the Pleistocene deposits. The Weichselian glaciation (115-12 ka) is characterised by alternating phases of warmer (interstadial) and colder (stadial) climate conditions. The response of large ice masses to this climatic fluctuation is one fundamental question that had to be answered to shape robust climate models. One of the most significant inland ice bodies in the Northern Hemisphere during the Quaternary glaciations was the Scandinavian Ice Sheet (SIS; Fig. 1a) as part of the Eurasian ice sheet. The southern maximum extent of the SIS during the Weichselian glaciation reached from Denmark across northern Germany through Poland and the Ukraine in the southeast of Europe. Repeated advances and retreats of the ice front shaped the landscape of much of northern and eastern Europe. However, after more than 130 years of Quaternary research, the timing and even the number of SIS advances into the south- western Baltic Sea area during the last glaciation are still unclear and far away from being solved (Hughes et al., 2016). Hence, the dynamics of the SIS are for most of the last glaciation only fragmentarily understood, particularly for the early to mid-Weichselian period.

The Pleistocene cliff outcrops around the peninsula of Jasmund (SW Baltic Sea; Figs. 1b, 2a) constitute a significant geological archive of the complex interaction between the dynamics of a large-scale ice sheet and climate fluctuations. The glacigenic and related deposits in the area of Jasmund have been studied since the end of the 19th century (see Kenzler et al., 2010, and references therein). In addition to the depositional environment and the stratigraphic position of the distinct Pleistocene layers (Fig. 2b), the formation of the glacitectonic complex of Jasmund as a whole has been another focus of research (Gehrmann, 2018; Gehrmann and Harding, 2018; Gehrmann et al., 2019).

For the reconstruction of the Weichselian SIS oscillations and their response to climate signals, an accurate and absolute age constraint of the different ice extents is required. Until now, the distribution of available age data for the south- 


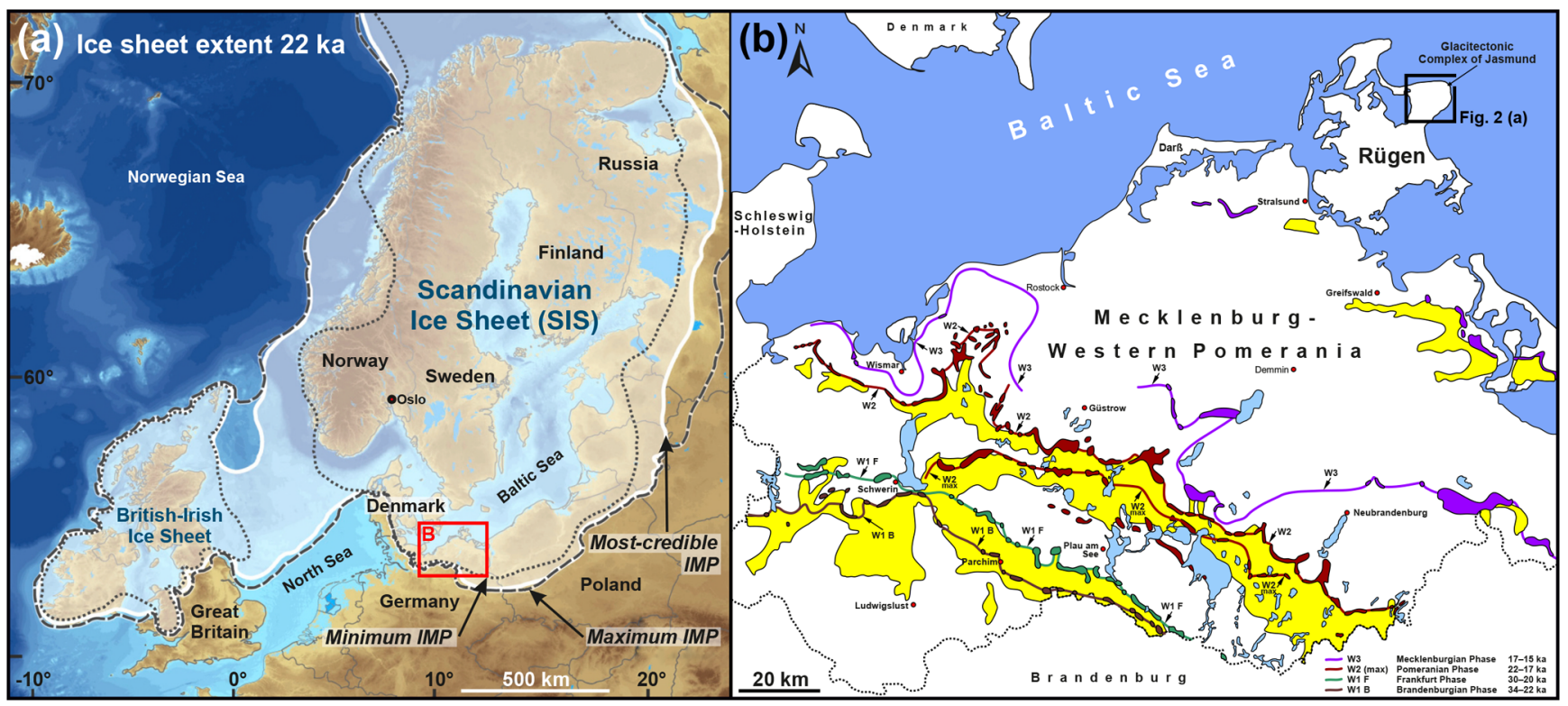

Figure 1. (a) Palaeogeographical map of NW Europe showing the ice extent at $22 \mathrm{ka}$ (ice marginal position - IMP; modified after Hughes et al., 2016); (b) overview map of northeastern Germany with the suggested main Weichselian ice marginal positions (W1-W3), including age classification (based on Litt et al., 2007; Heine et al., 2009; Lüthgens et al., 2011; Börner et al., 2014; Rinterknecht et al., 2014; Toucanne et al., 2015; Hardt et al., 2016; Hardt and Böse, 2016) and associated sandur deposits (yellow area) (based on Landesamt für Umwelt, Naturschutz und Geologie Mecklenburg-Vorpommern, 2010, and Schulz, 2011).

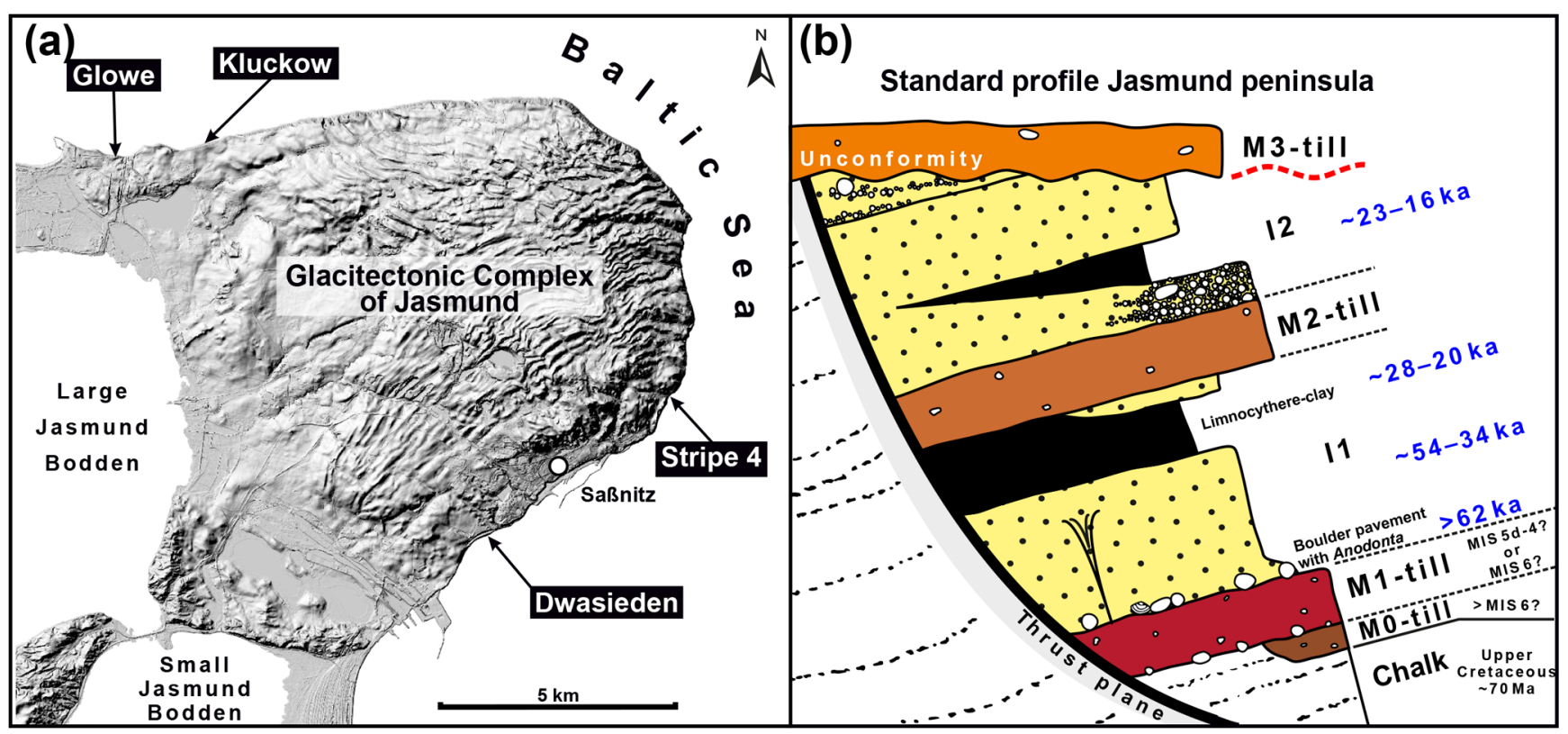

Figure 2. (a) Digital elevation model of Jasmund with cliff sections mentioned in the text; the hillshade relief with 10-fold exaggeration shows the glacitectonically structured morphology of the peninsula (based on @ GeoBasis-DE/M-V 2015, processed by Jörg Hartleib). (b) Generalised stratigraphical profile of a glacitectonically rafted imbricate structure at Jasmund comprising Upper Cretaceous chalk and paraconformably overlying Pleistocene deposits including the disconformably overlying Late Weichselian till complex M3 (modified after Kenzler et al., 2017); age estimations in blue based on the luminescence results shown in Figs. 4 and 3 (based on Kenzler et al., 2015, 2017; Pisarska-Jamroży et al., 2018). 
western Baltic Sea area has mainly focused on Denmark and Sweden (Hughes et al., 2016). For northern Germany, only sparse ages have been published, some of which contradict each other, which may be caused by the different dating techniques used in the studies. Recently, optically stimulated luminescence (OSL), infrared stimulated luminescence (IRSL), and terrestrial cosmogenic nuclide (TCN) dating methods have opened up new avenues to refine the chronology of single ice advances of the SIS during MIS 3 and 2 (e.g. Rinterknecht et al., 2014; Hardt et al., 2016; Kenzler et al., 2017).

\section{Luminescence dating approach and its application to the peninsula of Jasmund}

The main dating techniques for age constraint of the Weichselian ice marginal positions (IMPs) and associated deposits in NE Germany are surface exposure dating (SED; Heine et al., 2009; Rinterknecht et al., 2014), luminescence dating (e.g. Kenzler, 2017; Hardt, 2017), and radiocarbon dating (Steinich, 1992). In Mecklenburg-Western Pomerania, only a few of the SED-dated erratic boulders are related to Weichselian IMPs (e.g. Rinterknecht et al., 2014), and most of the radiocarbon ages are Late Glacial to Holocene (e.g. Lampe et al., 2016). Very few radiocarbon ages are available for the 50-20 ka timeframe (Steinich, 1992; Hughes et al., 2016), which is due to the very limited occurrence of in situ organic material in Weichselian deposits. The majority of the radiocarbon ages are related to the deglaciation period of the Late Weichselian, so they postdate an ice advance (minimum age estimations). Likewise, the SED of erratic boulders give the time of land stabilisation and thus yield a minimum age for an ice advance (Lüthgens et al., 2011). In contrast, with luminescence dating of (glaci)fluvial, (glaci)lacustrine, and aeolian sediments deposited in front of an active ice sheet, a direct age determination of the ice advance is possible. Several recent studies have clearly shown that luminescence dating can solve issues of the timing of the individual ice advances approaching NE Germany (e.g. Lüthgens et al., 2011; Kenzler et al., 2015, 2017; Hardt et al., 2016; Pisarska-Jamroży et al., 2018). These new luminescence age data raise the question of whether the traditional stratigraphy and interpretation of the main Weichselian ice advances of NE Germany have to be modified (Hardt, 2017; Kenzler, 2017).

Luminescence dating of quartz mineral grains (OSL) is well-suited to date silty to sandy sequences deposited in a sandur setting associated with ice marginal positions of Weichselian ice advances (e.g. Lüthgens et al., 2011; Hardt et al., 2016; Hardt, 2017). Furthermore, interstadial deposits of Weichselian age intercalated between till units have yielded reliable luminescence ages (Kenzler et al., 2015, 2017, 2018; Pisarska-Jamroży et al., 2018). Luminescence dating is based on the principle that the energy of the ionising radiation flux from the surrounding sediments $(\mathrm{U} / \mathrm{Th}$ series nuclides, $\mathrm{K}$ and $\mathrm{Rb}$ - alpha, beta, and gamma radiation) and of cosmic radiation is stored within the crystal lattice of quartz and feldspar minerals, due to impurities and lattice defects (Aitken, 1985). This creates an accumulation of energy with time. The signal is zeroed (bleached) when exposed to sunlight, which allows us to date the last transportation event (exposure to sunlight). Several successful dating protocols have been obtained with quartz (e.g. Murray and Wintle, 2000) and K-rich feldspar mineral grains (e.g. Thiel et al., 2011) as well as quality criteria (Wintle and Murray, 2006) and statistical approaches (e.g. Galbraith and Roberts, 2012), which has secured the reliability of luminescence age data.

The Jasmund ages presented here are based mainly on OSL measurements of quartz mineral grains since a standard issue for (glaci)fluvial sediments deposited in a sandur setting is partial bleaching of the palaeo-luminescence signal, which results in an overestimation of the true burial age (Fuchs and Owen, 2008). A reason for this heterogeneous bleaching could be a short transport distance and therefore an insufficient exposure time for the palaeo-luminescence signal in the crystal lattice to be brought to zero. Since only well-bleached quartz grains are useful for age calculation, the insufficiently bleached grains need to be separated out. This can be achieved by reducing the grain number on a single aliquot up to one single grain (single grain measurement; Duller, 2008). By analysing the equivalent dose distribution, the heterogeneously bleached quartz grain populations can be identified and discarded.

An essential part of luminescence dating is a detailed and careful sedimentological logging and facies analysis, as a reliable base for the reconstruction of the depositional environments. This in turn enables the selection of the most suitable horizons (depositional environments) for luminescence sampling, to reduce potential difficulties such as partial bleaching as much as possible. The main sedimentological approaches are classification and interpretation of the lithofacies based on primary deposition and erosional features (e.g. composition, structure, texture, bedding, lamination, and bed boundaries).

\section{The Weichselian glaciation in the southwestern Baltic Sea area}

The general results of the four investigated cliff outcrops are summarised in Fig. 3. The geological succession at Jasmund peninsula includes Cretaceous bedrock (limestone), paraconformably overlain by Pleistocene deposits. Up to four till complexes (from bottom to top: M0, M1, M2, and M3) can be distinguished, which are separated from each other (with the exception of M0-M1) by mostly clayey to gravely units (I1 and I2). Age estimations of the lowermost till units M0 and M1 range from Elsterian to Saalian to mid-Weichselian (e.g. Steinich, 1992; Müller and Obst, 2006; Niedermeyer et al., 2010; Fig. 2b). Information about the early and mid- 


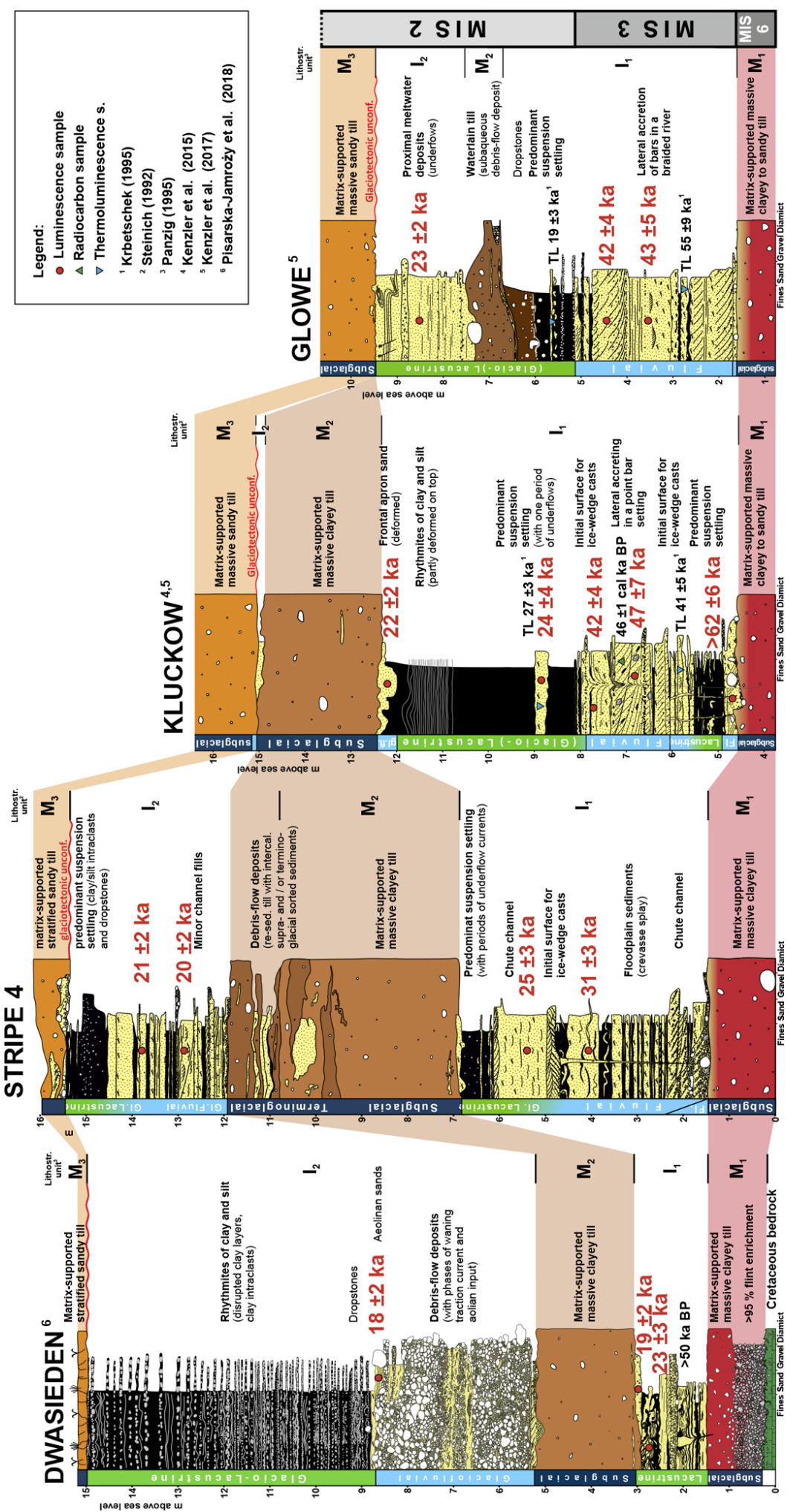

Figure 3. Summarised lithological profiles of four cliff outcrops around the peninsula of Jasmund. The correlation between the deposits of the outcrops was made by lithofacies analyses, physical age chronology, and fine-gravel analyses. Separated by till sheets, two distinct well-sorted sediment complexes (I1 and I2) of MIS 3 and MIS 2 age, respectively, are preserved in the outcrops. The lower one (I1) can be correlated across the whole of Jasmund, whereas the upper one (I2) is tailing out towards the northwest. The stratigraphical log from Glowe (profile metres 100-110, Fig. 5a; modified after Kenzler et al., 2017) indicates lithostratigraphical units, depositional environments, and OSL (red dots) and thermoluminescence (TL) ages (blue triangles). The lithological log of Kluckow (Fig. 3b) is based on Kenzler et al. (2017), whereas the log of Dwasieden is modified from Pisarska-Jamroży et al. (2018). Facies codes after Benn and Evans (2010). 

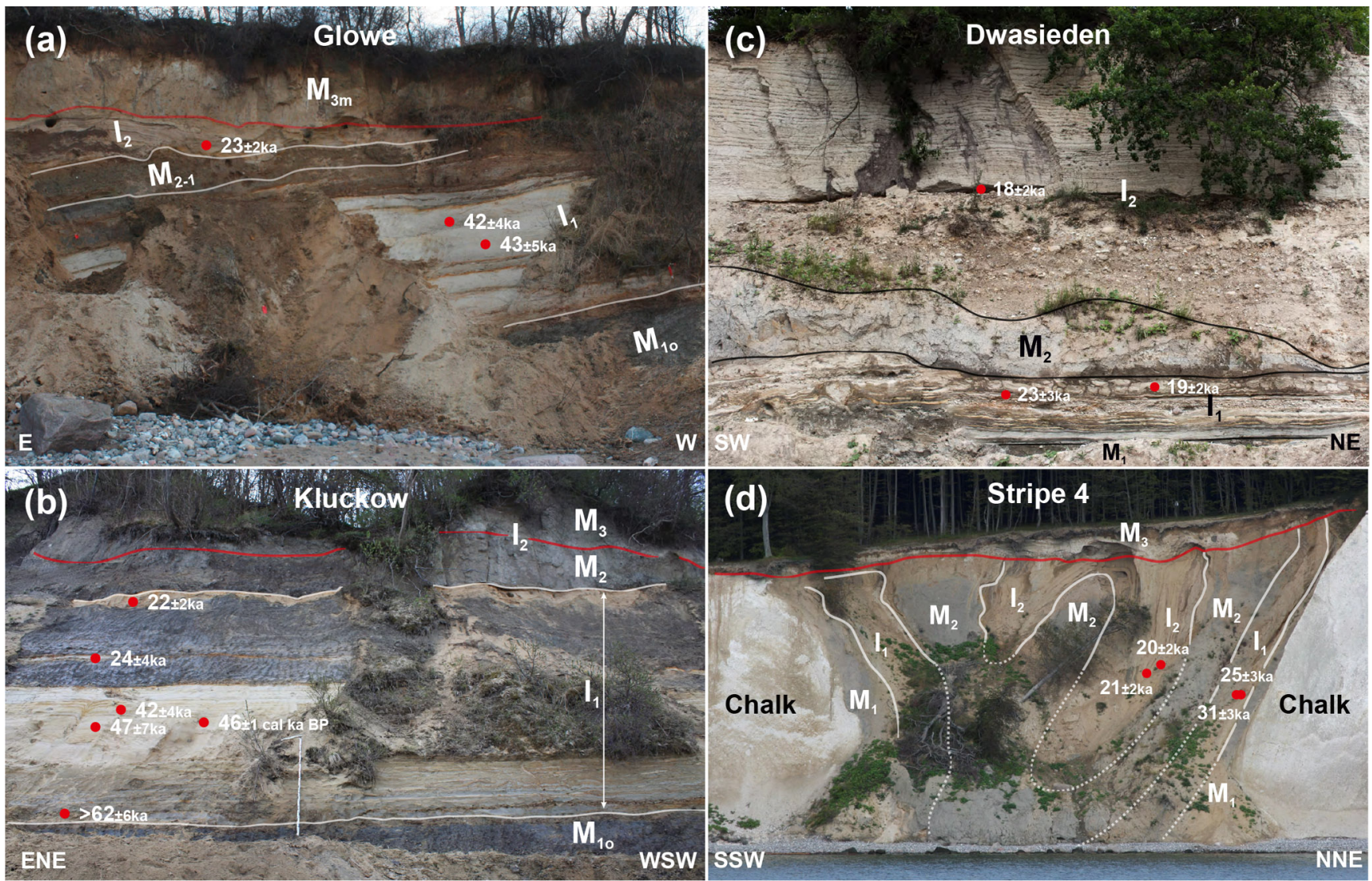

Figure 4. Photographs of (a) Glowe (profile metres 95-110, Figs. 2a and 5a; modified after Kenzler et al., 2017) and (b) Kluckow cliff sections (profile metres 50-70, Figs. 2a and 5b; modified after Kenzler et al., 2017). (c) Cliff section of Dwasieden with thick layers of glacifluvial and glacilacustrine units at the top (Figs. 2a and 3). (d) Pleistocene Stripe 4 sandwiched between two chalk complexes (Figs. $2 a$ and 3). The filled dots highlight the sample position for luminescence dating including their age. The semi-transparent red lines represent the base M3 glacitectonic unconformity.

Weichselian time are very rare because sediments of this period are absent/eroded or were never deposited. The existence of an advance of the SIS between the end of the Eemian (115 ka) and the beginning of MIS 3 (57 ka) is unlikely but not impossible. The oldest luminescence ages from the base of the intercalated I1 unit (Figs. 2b, 3, 4, and 5) indicate a deposition of the underlying till (M1) older than $62 \pm 6 \mathrm{ka}$. The landscape during the early MIS 3 was dominated by small lakes and arctic to subarctic climate conditions, including a change to moderate summers and cool winters. The deposition during the subsequent period (roughly between 54 and $34 \mathrm{ka}$; Fig. 2b) occurred in a fluvial environment (meandering/braided river systems) embedded in a steppe-like landscape. Palaeontological evidence indicates warmer interstadial climate conditions. Preserved ice wedge casts signal colder temperatures at the end of MIS 3. A correlation with the Klintholm advance documented in Denmark (HoumarkNielsen, 2010) can be assumed (Kenzler et al., 2017). Indications for the existence of a MIS 3 ice advance reaching Jasmund are not available. The transition of MIS 3 and 2 was characterised by the deposition in a glacilacustrine basin, which can be formed due to the blocking effect of the Kattegat advance of the SIS between 29 and $26 \mathrm{ka}$ (HoumarkNielsen, 2010; Kenzler et al., 2017). The first dated Weichselian ice advance, which deposited the M2 till complex, occurred around $23 \pm 2 \mathrm{ka}$ (Brandenburgian Phase; Fig. 1a). The subsequent ice oscillations during the Pomeranian and Mecklenburgian phases took place between 20 and $15 \mathrm{ka}$ (Toucanne et al., 2015; Kenzler et al., 2017; Hardt and Böse, 2016).

\section{The Cretaceous-Pleistocene sequence of Glowe}

The first stop of the day will lead us to the steep coast of Glowe (Fig. 1a). This cliff section illustrates the geological structure of the glacitectonic complex of Jasmund, as well as the Cretaceous-Pleistocene succession in this area (Figs. $2 b$ and 3). Along the more than $300 \mathrm{~m}$ long coastal section, a chalk anticline deposit and a paraconformably overlying Pleistocene deposit crop out. A main feature is the very im- 
(a)

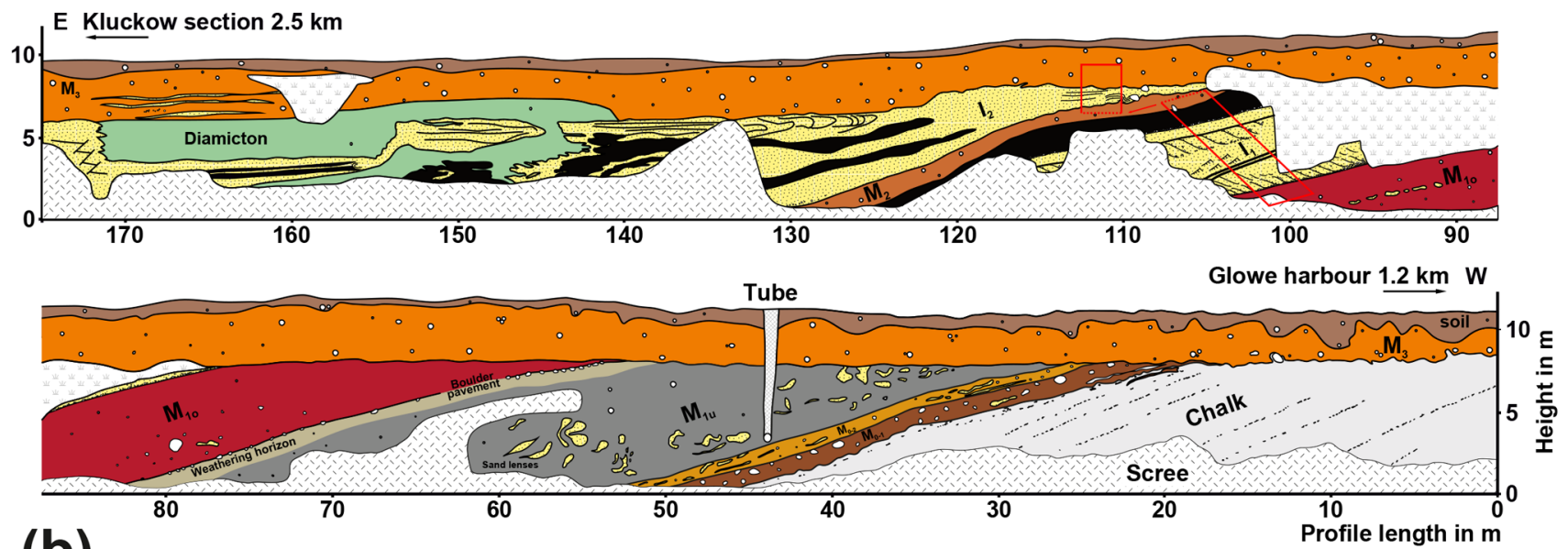

(b)

Kluckow cliff section
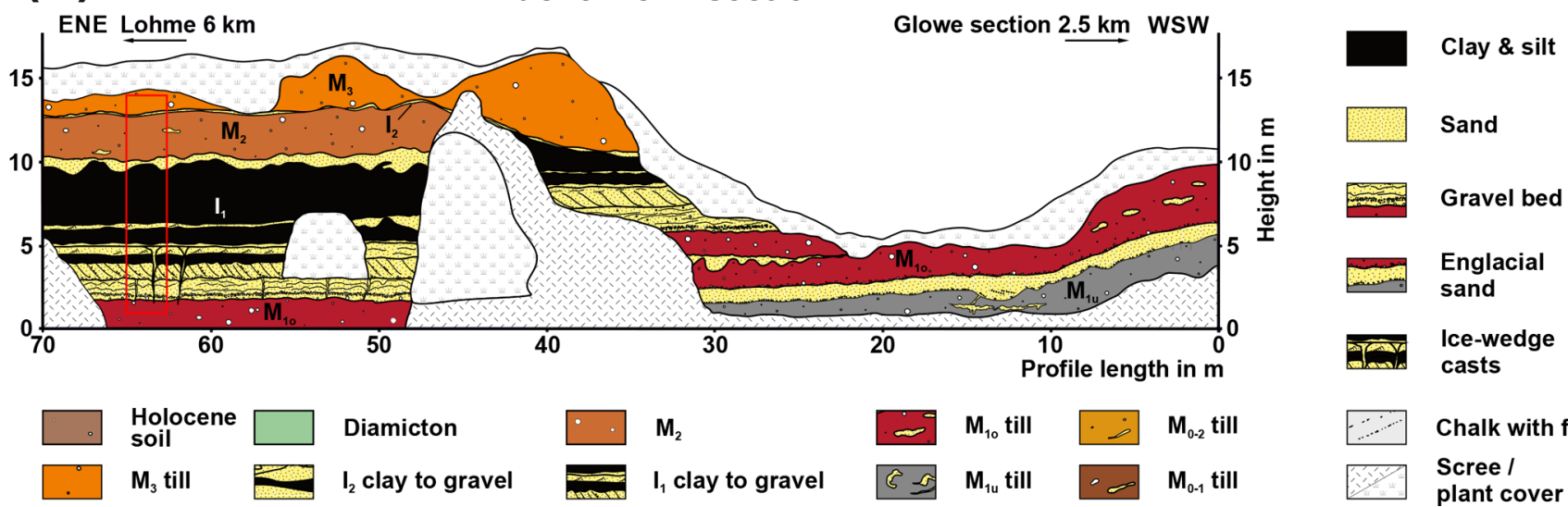

Figure 5. Sketches of the (a) Glowe and (b) Kluckow cliff sections (Fig. 2a for cliff locations). The sketches show the outcrop situation during the years 2010 and 2011, respectively (modified after Kenzler et al., 2017). The red boxes display the locations of the lithofacies analyses (Fig. 3).

pressive late Weichselian glacitectonic unconformity, visible in the upper part of the cliff (Fig. 4a). The Pleistocene sequence includes at least four diamictic units, which are correlated to advances of the SIS during the Elsterian, Saalian, and Weichselian glaciations (Panzig, 1995; Niedermeyer et al., 2010; Kenzler et al., 2017). The cliff also exhibits two horizons of well-sorted siliciclastic deposits intercalated between diamictic units (I1 and I2; Figs. 3, 4a, and 5). The depositional environment of about the last $50 \mathrm{kyr}$ has been reconstructed with luminescence ages and sedimentological interpretations. Ice-free conditions dominated the study area during MIS 3 and early MIS 2. The deposition occurred in braided river systems under, at least partly, interstadial climate conditions. At the transition from MIS 3 to MIS 2, a cooling trend occurred, leading to the formation of a glacilacustrine basin at the beginning of MIS 2. This cooling correlates with the Kattegat advance of the SIS known from Denmark (Houmark-Nielsen, 2010). The first advance of the SIS reached the area of Glowe during the Last Glacial Maximum
( $23 \pm 2 \mathrm{ka}$; Kenzler et al., 2017). Variations in the meltwater supply from the nearby ice front dominated the deposition during this time, including debris flows (M2), which entered the ice-marginal basin. After the subsequent formation of the glacitectonic complex of Jasmund during the Pomeranian advance (ca. 20-18 ka), the glacitectonic unconformity was created together with the subsequent deposition of the youngest diamictic unit (M3).

In addition, the Pleistocene deposits outcropping at the cliffs of Kluckow, Stripe 4, and Dwasieden (Figs. 2a and 4) contain valuable sedimentological and stratigraphical information about the Weichselian glaciation (Fig. 3) that has improved our knowledge about the dynamics of the SIS in this area.

Data availability. All data relevant for this contribution are presented within the article itself or the publications cited. 
Author contributions. MK and HH carried out fieldwork. MK processed, measured, and analysed the luminescence samples, as well as developed the illustrations. Both authors prepared the paper.

Competing interests. The authors declare that they have no conflict of interest.

Acknowledgements. This research was funded by the German Research Foundation (DFG projects HU 804/6-1, FR 877/16-1). Marie-Elaine van Egmond (Halle) is thanked for her professional English proofreading of a previous version of the paper. We are grateful to reviewer Kay Krienke (Llur Flintbek) for his valuable comments and feedback. We acknowledge support for the article processing charge from the DFG (no. 393148499) and the Open Access Publication Fund of the University of Greifswald.

Financial support. This research has been supported by the DFG (German Research Foundation, grant no. 393148499 and projects HU 804/6-1, FR 877/16-1) and the Open Access Publication Fund of the University of Greifswald.

\section{References}

Aitken, M. J.: Thermoluminescence dating, Academic Press, London, UK, 1985.

Benn, D. I. and Evans, D. J. A.: Glaciers and Glaciations, Hodder Education, London, UK, 802 pp., 2010.

Börner, A., Rinterknecht, V., Bourelès, D., and Braucher, R.: First results from surface exposure dating of glacial boulders in ice marginal belts of Mecklenburg-Western Pomerania (NEGermany) using in-situ cosmogenic Beryllium-10, Journal for the Geological Science, 41, 123-143, 2014.

Duller, G. A. T.: Single-grain optical dating of Quaternary sediments: why aliquot size matters in luminescence dating, Boreas, 37, 589-612, 2008.

Fuchs, M. and Owen, L. A.: Luminescence dating of glacial and associated sediments: review, recommendations and future directions, Boreas, 37, 636-659, 2008.

Galbraith, R. F. and Roberts, R. G.: Statistical aspects of equivalent dose and error calculation and display in OSL dating: an overview and some recommendations, Quat. Geochronol., 11, 127, 2012.

Gehrmann, A.: The multi-stage structural development of the Upper Weichselian Jasmund Glacitectonic Complex (Rügen, NE Germany), $\mathrm{PhD}$ thesis, University Greifswald, Greifswald, Germany, 278 pp., 2018.

Gehrmann, A. and Harding, C.: Geomorphological Mapping and Spatial Analyses of an Upper Weichselian Glacitectonic Complex based on LiDAR Data, Jasmund Peninsula (NE Rügen), Germany, Geosciences, 8, 208, https://doi.org/10.3390/geosciences8060208, 2018.

Gehrmann, A., Meschede, M., Hüneke, H., and Schack Pedersen, S. A.: Sea cliff at Kieler Ufer (Pleistocene stripes 11-16) - Largescale architecture and kinematics of the Jasmund Glacitectonic Complex, DEUQUA Spec. Pub., this volume, 2019.
Hardt, J.: Weichselian phases and ice dynamics of the Scandinavian Ice Sheet in northeast Germany, PhD thesis, FU Berlin, Berlin, Germany, 137 pp., 2017.

Hardt, J. and Böse, M.: The timing of the Weichselian Pomeranian ice marginal position south of the Baltic Sea: A critical review of morphological and geochronological results, Quatern. Int., 478, 51-58, 2016.

Hardt, J., Lüthgens, C., Hebenstreit, R., and Böse, M.: Geochronological (OSL) and geomorphological investigations at the presumed Frankfurt ice marginal position in northeast Germany, Quaternary Sci. Rev., 154, 85-99, 2016.

Heine, K., Reuther, A., Thieke, H. U., Schulz, R., Schlaak, N., and Kubik, P.: Timing of Weichselian ice marginal positions in Brandenburg (northeastern Germany) using cosmogenic in situ ${ }^{10} \mathrm{Be}$, Z. Geomorphol., 53, 433-454, 2009.

Houmark-Nielsen, M.: Extent, age and dynamics of Marine Isotope Stage 3 glaciation in the southwestern Baltic Basin, Boreas, 39, 343-359, 2010.

Hughes, A. L. C., Gyllencreutz, R., Lohne, Ø. S., Mangerud, J., and Svendsen, J. I.: The last Eurasian ice sheet - a chronological database and time-slice reconstruction, DATED-1, Boreas, 45, 1-45, 2016.

Kenzler, M.: Ice-sheet dynamics and climate fluctuations during the Weichselian glaciation along the southwestern Baltic Sea coast, PhD thesis, University Greifswald, Greifswald, Germany, 169 pp., 2017.

Kenzler, M., Obst, K., Hüneke, H., and Schütze, K.: Glazitektonische Deformation der kretazischen und pleistozänen Sedimente an der Steilküste von Jasmund nördlich des Königsstuhls (Rügen), Brandenburg. geowiss. Beitr., 17, 107-122, 2010.

Kenzler, M., Tsukamoto, S., Meng, S., Thiel, C., Frechen, M., and Hüneke, H.: Luminescence dating of Weichselian interstadial sediments from the German Baltic Sea coast, Quat. Geochronol. 30, 215-256, 2015.

Kenzler, M., Tsukamoto, S., Meng, S., Frechen, M., and Hüneke, H.: New age constraints from the SW Baltic Sea area - implications for Scandinavian Ice Sheet dynamics and palaeoenvironmental conditions during MIS 3 and early MIS 2, Boreas, 46, 34-52, 2017.

Kenzler, M., Rother, H., Hüneke, H., Frenzel, P., Strahl, J., Tsukamoto, S., Li, Y., Meng, S., Gallas, J., and Frechen, M. A multi-proxy palaeoenvironmental and geochronological reconstruction of the Saalian-Eemian-Weichselian succession at Klein Klütz Höved, NE Germany, Boreas, 47, 114-136, 2018.

Krbetschek, M. R.: Lumineszenz-Datierungen quartärer Sedimente Mittel-, Ost- und Nordostdeutschlands. PhD thesis, TU Bergakademie Freiberg, Freiberg, Germany, 122 pp., 1995.

Lampe, R., Janke, W., Schult, M., Meng, S., and Lampe, M.: Multiproxy-Untersuchungen zur Paläoökologie und -hydrologie eines spätglazial- bis frühholozänen Flachsees im nordostdeutschen Küstengebiet (Glowe-Paläosee/Insel Rügen), E\&G Quaternary Sci. J., 65, 41-75, https://doi.org/10.3285/eg.65.1.03, 2016.

Landesamt für Umwelt, Naturschutz und Geologie: Geologische Karte von Mecklenburg-Vorpommern - Übersichtskarte $1: 500000$ - Oberfläche, Güstrow, Germany, 2010.

Litt, T., Behre, K.-E., Meyer, K.-D., Stephan, H.-J., and Wansa, S.: Stratigraphische Begriffe für das Quartär des nord- 
deutschen Vereisungsgebietes, E\&G Quaternary Sci. J., 56, 765, https://doi.org/10.3285/eg.56.1-2.02, 2007.

Lüthgens, C., Böse, M., and Preusser, F.: Age of the Pomeranian ice-marginal position in northeastern Germany determined by Optically Stimulated Luminescence (OSL) dating of glaciofluvial sediments, Boreas, 40, 598-615, 2011.

Müller, U. and Obst, K.: Lithostratigraphy and bedding of the Pleistocene deposits in the area of Lohme (Jasmund/Rügen), Journal for the Geological Science, 34, 39-54, 2006.

Murray, A. S. and Wintle, A. G.: Luminescence dating of quartz using an improved single-aliquot regenerative-dose protocol, Radiat. Meas., 32, 57-73, 2000.

Niedermeyer, R.-O., Kanter, L., Kenzler, M., Panzig, W.-A., Krienke, K., Ludwig, A.-O., Schnick, H. H., and Schütze, K.: Rügen Island (I) - Facies, stratigraphy, structural architecture and geological hazard potential of Pleistocene deposits of the Jasmund cliff coast, in: Eiszeitlandschaften in MecklenburgVorpommern, edited by: Lampe, R. and Lorenz, S., Geozon Science Media, Greifswald, Germany, 50-71, 2010.

Panzig, W.-A.: Zum Pleistozän von Rügen, Terra Nostra, 6, 177200, 1995.

Pisarska-Jamroży, M., Belzyt, S., Börner, A., Hoffmann, G., Hüneke, H., Kenzler, M., Obst, K., Rother, H., and van Loon, A. J.: Evidence for glacio-isostatically induced crustal faulting in front of an advancing land-ice mass (Rügen Island, NE Germany), Tectonophysics, 745, 338-348, 2018.
Rinterknecht, V., Börner, A., Bourlès, D., and Braucher, R.: Cosmogenic ${ }^{10} \mathrm{Be}$ dating of ice sheet marginal belts in MecklenburgVorpommern, Western Pomerania (northeast Germany), Quat. Geochronol., 19, 42-51, 2014.

Schulz, W.: Streifzüge durch die Geologie des Landes Mecklenburg-Vorpommern, Schwerin, Germany, 216 pp., 2011.

Steinich, G.: Die stratigraphische Einordnung der Rügen-Warmzeit, Journal for the Geological Sciences, 20, 125-154, 1992.

Thiel, C., Buylaert, J.-P., Murray, A. S., Terhorst, B., Hofer, I., Tsukamoto, S., and Frechen, M.: Luminescence dating of the Stratzing loess profile (Austria) - testing the potential of an elevated temperature post-IR IRSL protocol, Quatern. Int., 234, 23 31, 2011.

Toucanne, S., Soulet, G., Freslon, N., Silva Jacinto, R., Dennielou, B., Zaragosi, S., Eynaud, F., Bourillet, J.-F., and Bayon, G.: Millennial-scale fluctuations of the European Ice Sheet at the end of the glacial, and their potential impact on global climate, Quaternary Sci. Rev., 123, 113-133, 2015.

Wintle, A. G. and Murray, A. S.: A review of quartz optically stimulated luminescence characteristics and their relevance in singlealiquot regeneration dating protocols, Radiat. Meas., 41, 369391, 2006. 